\title{
Antioxidant and Antihyperglycemic Properties of Three Banana Cultivars (Musa spp.)
}

\author{
Bukola C. Adedayo, ${ }^{1}$ Ganiyu Oboh, ${ }^{1}$ Sunday I. Oyeleye, ${ }^{1,2}$ and Tosin A. Olasehinde ${ }^{1,3}$ \\ ${ }^{1}$ Functional Foods and Nutraceuticals Unit, Department of Biochemistry, Federal University of Technology, PMB 704, \\ Akure 340001, Nigeria \\ ${ }^{2}$ Department of Biomedical Technology, Federal University of Technology, PMB 704, Akure 340001, Nigeria \\ ${ }^{3}$ Nutrition and Toxicology Division, Food Technology Department, Federal Institute of Industrial Research, Oshodi, \\ PMB 21023, Lagos 10001, Nigeria \\ Correspondence should be addressed to Bukola C. Adedayo; chrisadeb2013@yahoo.com
}

Received 3 January 2016; Revised 9 August 2016; Accepted 21 August 2016

Academic Editor: Rosa Tundis

Copyright (C) 2016 Bukola C. Adedayo et al. This is an open access article distributed under the Creative Commons Attribution License, which permits unrestricted use, distribution, and reproduction in any medium, provided the original work is properly cited.

Background. This study sought to investigate the antioxidant and antihyperglycemic properties of Musa sapientum (Latundan banana) (MSL), Musa acuminata (Cavendish banana) (MAC), and Musa acuminate (Red Dacca) (MAR). Materials and Methods. The sugar, starch, amylose, and amylopectin contents and glycemic index (GI) of the three banana cultivars were determined. Furthermore, total phenol and vitamin C contents and $\alpha$-amylase and $\alpha$-glucosidase inhibitory effects of banana samples were also determined. Results. MAC and MAR had the highest starch, amylose, and amylopectin contents and estimated glycemic index (eGI) with no significant different while MSL had the lowest. Furthermore, MAR (1.07 mg GAE/g) had a higher total phenol content than MAC (0.94 mg GAE/g) and MSL (0.96 mg GAE/g), while there was no significant difference in the vitamin C content. Furthermore, MAR had the highest $\alpha$-amylase $\left(\mathrm{IC}_{50}=3.95 \mathrm{mg} / \mathrm{mL}\right)$ inhibitory activity while $\mathrm{MAC}$ had the least $\left(\mathrm{IC}_{50}=4.27 \mathrm{mg} / \mathrm{mL}\right)$. Moreover, MAC and MAR inhibited glucosidase activity better than MSL ( $\left.\mathrm{IC}_{50} 3.47 \mathrm{mg} / \mathrm{mL}\right)$. Conclusion. The low sugar, GI, amylose, and amylopectin contents of the three banana cultivars as well as their $\alpha$-amylase and $\alpha$-glucosidase inhibitory activities could be possible mechanisms and justification for their recommendation in the management of type-2 diabetes.

\section{Introduction}

Previous experimental investigations involving the treatment and/or management of diabetes have revealed that decrease in blood glucose in diabetic patients with hyperglycemia can reduce diabetic consequences and prevent risk of diabetic complications such as hypertension [1]. Many reports have shown diverse therapeutic and dietary strategies in the treatment and/or management of diabetes and its complications [2,3]. Willett et al. [4] reported that consumption of slowly absorbed and low glycemic index carbohydrates can contribute to low blood glucose response in diabetic individuals. Furthermore, some epidemiological studies have revealed that replacing high glycemic index foods with low glycemic foods can reduce the risk of diabetes $[5,6]$. Other reports have also revealed that inhibition of carbohydrate hydrolyzing enzymes ( $\alpha$-amylase and $\alpha$-glucosidase) can retard the release of glucose into the blood stream thereby preventing hyperglycemia [7-9]. The use of dietary approach for the management of diabetes has gained a lot of interest recently. Natural inhibitors of $\alpha$-amylase and $\alpha$-glucosidase activity present in plant foods have little or no side effects and more advantages due to their biologically active constituents such as polyphenols. Augmenting endogenous antioxidants via consumption of plant-based antioxidant compounds such as polyphenols can prevent oxidative stress, another culprit in pathophysiology of type 2 diabetes which is a major risk of diabetic complications [10, 11].

Banana is one of the most consumed fruits in tropical and subtropical regions of the world [12]. In Nigeria some 
of the most common edible banana cultivars include Musa sapientum (Latundan banana) (MSL) also referred to as Musa paradisiaca, Musa acuminata (Cavendish banana) (MAC), and Musa acuminate (Red Dacca) (MAR). Kanazawa and Sakakibara [13] reported the antioxidant properties and radical scavenging activities of some banana species. There are also some reports on the glycemic index and antihyperglycemic and antidiabetic properties of Musa paradisiaca $[14,15]$. However, to the best of our knowledge, there is dearth of information on the holistic and comparative studies on the antioxidant and antihyperglycemic properties of some banana cultivars (Musa spp.). This present study aims to determine the sugar, starch, amylose and amylopectin contents, and estimated glycemic index (eGI) as well as total phenol and vitamin C contents of three banana [Musa sapientum (Latundan banana) (MSL), Musa acuminata (Cavendish banana) (MAC), and Musa acuminate (Red Dacca) (MAR)] cultivars. The antioxidant properties and inhibitory effects of the banana cultivars on carbohydrate trimming enzymes ( $\alpha$ amylase and $\alpha$-glucosidase activities) were also determined.

\section{Materials and Methods}

2.1. Sample Collection. Three different varieties of matured ripe banana fruits, Musa sapientum (Musa paradisiaca), Musa acuminata (Red Dacca), and Musa acuminata (Cavendish banana), were obtained from a local market in Akure, Ondo State, Nigeria. Authentication of the samples was carried out at the Department of Crop Soil and Pest (CSP), Federal University of Technology, Akure, Nigeria.

2.2. Chemicals and Reagents. Gallic acid and Folin-Ciocalteu's reagent were procured from Sigma-Aldrich (St. Louis, MO), while DPPH was from Sigma-Aldrich Chemie (Steinheim, Germany). Unless stated otherwise, all the chemicals and reagents used were of analytical grades and the water was glass distilled.

2.3. Aqueous Sample Preparation. The edible portion (pulp) was separated from the peels. The pulp was spliced and oven dried at $50^{\circ} \mathrm{C}$ and thereafter milled into powdery form. Each sample $(10 \mathrm{~g})$ was soaked in $100 \mathrm{~mL}$ distilled water for $16 \mathrm{~h}$ on an orbital shaker [16]. The mixture was filtered using Whatman filter (number 2) and later centrifuged at $400 \times \mathrm{g}$ for $10 \mathrm{~min}$ to obtain a clear supernatant which was used for vitamin $\mathrm{C}$ and total phenol contents as well as $\alpha$-amylase and $\alpha$-glucosidase activities inhibitory assays. Dried powder sample was kept for starch, sugar, and amylose contents and eGI analyses.

2.4. Starch and Sugar Determination. Starch and sugar were extracted from $0.02 \mathrm{~g}$ of the pulverized sample using $80 \%$ hot ethanol. The mixture was then centrifuged at $2000 \mathrm{rpm}$ for $10 \mathrm{~min}$ after which the supernatant was decanted and used for free sugar analysis, while the residue was used for starch analysis [17]. For sugar analysis, $0.2 \mathrm{~mL}$ of the diluted supernatant was mixed with $0.5 \mathrm{~mL}$ of phenol solution (5\%) and $2.5 \mathrm{~mL}$ of $\mathrm{H}_{2} \mathrm{SO}_{4}$ (absolute). The mixture was allowed to cool to room temperature before reading the absorbance at $490 \mathrm{~nm}$. The residue was hydrolyzed with $7.5 \mathrm{~mL}$ of perchloric acid for $1 \mathrm{hr}$, diluted to $25 \mathrm{~mL}$ with distilled water, and filtered through Whatman filter paper (number 2). Then $0.05 \mathrm{~mL}$ of the filtrate was mixed with $0.5 \mathrm{~mL}$ of phenol solution $(5 \%)$ and $2.5 \mathrm{~mL} \mathrm{H}_{2} \mathrm{SO}_{4}$ (absolute). The mixture was allowed to cool to room temperature and the absorbance was read at $490 \mathrm{~nm}$. Starch and total free sugar contents of the sample were calculated from a glucose standard curve prepared along with the sample.

2.5. Amylose and Amylopectin Content Determination. The samples $(0.1 \mathrm{~g})$ were mixed with $1 \mathrm{~mL}$ of $95 \%$ ethanol and $9.2 \mathrm{~mL}$ of $1 \mathrm{~N} \mathrm{NaOH}$ and heated at $100^{\circ} \mathrm{C}$ in a water bath for $10 \mathrm{~min}$. After cooling, $0.5 \mathrm{~mL}$ of diluted sample was mixed with $0.1 \mathrm{~mL}$ of $1 \mathrm{~N}$ acetic acid solution and $0.2 \mathrm{~mL}$ of iodine solution $\left(0.2 \% \mathrm{I}_{2}\right.$ in $\left.2 \% \mathrm{KI}\right)$. The test mixture was made up to $10 \mathrm{~mL}$ with distilled water, mixed, and left for $20 \mathrm{~min}$ for color development. Thereafter, the absorbance was read at $620 \mathrm{~nm}$ and amylase content was calculated using standard amylase. Amylopectin was calculated using the following formula: amylopectin $=$ starch value - amylose value [18] .

2.6. Determination of Estimated Glycemic Index. The sample (25 mg) was weighed into a beaker; thereafter, $1 \mathrm{mg}$ of pepsin in $10 \mathrm{~mL} \mathrm{HCl}+\mathrm{KCl}$ buffer $(\mathrm{pH} 1.5)$ was added and then incubated at $40^{\circ} \mathrm{C}$ for $60 \mathrm{~min}$ in a shaking water bath. The digest was then diluted with phosphate buffer $\mathrm{pH} 6.9$ before the addition of $2.5 \mathrm{~mL} \alpha$-amylase solution and incubated at $37^{\circ} \mathrm{C} .200 \mu \mathrm{L}$ of the digest was taken into test tube at 30 min interval $(0,30,60,90,120,150$, and $180 \mathrm{~min})$. The aliquots were boiled for $15 \mathrm{~min}$ before addition of $500 \mu \mathrm{L}$ sodium acetate $\mathrm{pH} 4.75$ followed by $5 \mu \mathrm{L}$ of $\alpha$-glucosidase solution and then incubated for $45 \mathrm{~min}$ at $60^{\circ} \mathrm{C} .200 \mu \mathrm{L} \mathrm{DNSA}$ solution was added and incubated for $5 \mathrm{~min}$ at $100^{\circ} \mathrm{C}$ followed by addition of $2 \mathrm{~mL}$ distilled water and then centrifuge at $3000 \mathrm{rpm}$ for $5 \mathrm{~min}$. The supernatant was decanted and the absorbance was read at $540 \mathrm{~nm}$. The sum of areas under curve for each sample was divided by the sum of areas under curve for standard glucose and multiplied by 100 . The value obtained is the glycemic index [19].

2.7. Determination of Total Phenol Content. The total phenol content was determined according to the method of Singleton et al. [20]. Briefly, appropriate dilutions of the banana samples were oxidized with $2.5 \mathrm{~mL} 10 \%$ Folin-Ciocalteu's reagent (v/v) and neutralized by $2.0 \mathrm{~mL}$ of $7.5 \%$ sodium carbonate. The reaction mixture was incubated for $40 \mathrm{~min}$ at $45^{\circ} \mathrm{C}$ and the absorbance was measured at $765 \mathrm{~nm}$ in the spectrophotometer. The total phenol content was subsequently calculated as gallic acid equivalent.

2.8. Determination of Vitamin C Content. The vitamin C content of the samples was determined according to the method used by Ademiluyi et al. [21]. Briefly $5 \mathrm{~g}$ of the samples was sampled by $100 \mathrm{~mL} \mathrm{H}_{2} \mathrm{O}$, and $10 \mathrm{~mL}$ of the sample was mixed with $25 \mathrm{~mL}$ of glacial acetic acid and titrated 


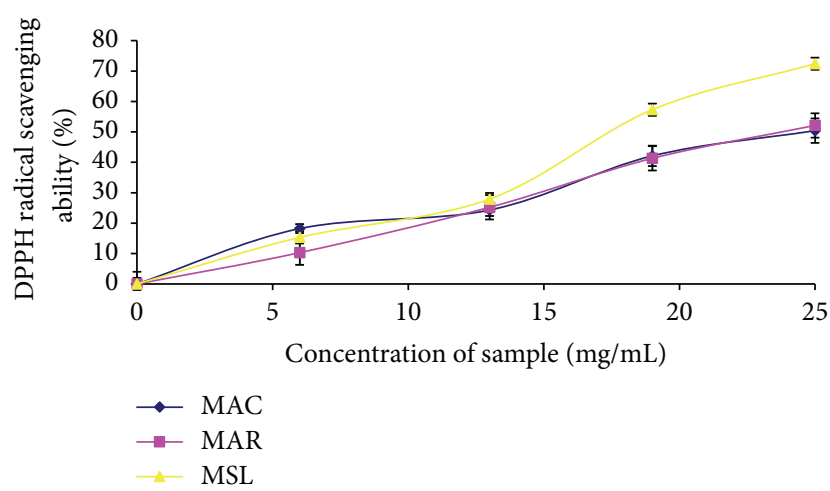

FIGURE 1: DPPH radical scavenging ability of Musa sapientum (Latundan banana) (MSL), Musa acuminata (Cavendish banana) (MAC), and Musa acuminate (Red Dacca) (MAR).

against standardized 2,6-dichloroindophenol (0.05 g/100 mL) solution.

2.9. Determination of $A B T S^{*}$ Scavenging Ability. The total antioxidant capacity was determined based on 2,2-azinobis 3ethylbenzothiazoline 6-sulfonate radical (ABTS ${ }^{*}$ ) scavenging ability of the sample according to the method described by Re et al. [22]. ABTS radical was generated by reacting ABTS aqueous solution $(7 \mathrm{mM})$ with $\mathrm{K}_{2} \mathrm{~S}_{2} \mathrm{O}_{8}(2.45 \mathrm{mM}$, final concentration) in the dark for $16 \mathrm{~h}$ and adjusting the absorbance at $734 \mathrm{~nm}$ to 0.700 with ethanol. Appropriate dilution of the samples $(0.2 \mathrm{~mL})$ was added to $2.0 \mathrm{~mL}$ ABTS radical solution and the absorbance was measured at $734 \mathrm{~nm}$ after 15 min. The trolox equivalent antioxidant capacity (TEAC) was subsequently calculated using trolox as the standard.

2.10. Free Radical Scavenging Assay. The free radical scavenging ability of the sample against DPPH radical was evaluated as described by Gyamfi et al. [23]. Briefly, an appropriate dilution of the samples $(1 \mathrm{~mL})$ was mixed with $1 \mathrm{~mL} 0.4 \mathrm{mM}$ DPPH radicals in methanolic solution. The mixture was left in the dark for $30 \mathrm{~min}$, and the absorbance was taken at $516 \mathrm{~nm}$. The control was carried out by using $2 \mathrm{~mL}$ DPPH solution without the test samples. The DPPH radical scavenging ability was subsequently calculated as percentage control (Figure 1).

2.11. $\alpha$-Amylase Inhibition Assay. The aqueous samples $(500 \mu \mathrm{L})$ and $500 \mu \mathrm{L}$ of $0.02 \mathrm{M}$ of sodium phosphate buffer (pH 6.9 with $0.006 \mathrm{~mol} \cdot \mathrm{L}^{-1} \mathrm{NaCl}$ ) containing hog pancreatic $\alpha$-amylase (EC 3.2.1.1; $0.5 \mathrm{mg} / \mathrm{mL}$ ) were incubated at $25^{\circ} \mathrm{C}$ for $10 \mathrm{~min}$. Then, $500 \mu \mathrm{L}$ of $1 \%$ starch solution in $0.02 \mathrm{M}$ sodium phosphate buffer ( $\mathrm{pH} 6.9$ with $0.006 \mathrm{M} \mathrm{NaCl})$ was added to the reaction mixture. Thereafter, the reaction mixture was incubated at $25^{\circ} \mathrm{C}$ for $10 \mathrm{~min}$ and stopped with $1.0 \mathrm{~mL}$ of dinitrosalicylic acid (DNSA). The mixture was then incubated in boiling water for $5 \mathrm{~min}$ and cooled to room temperature. The reaction mixture was then diluted by adding $10 \mathrm{~mL}$ of distilled water, and absorbance was measured at $540 \mathrm{~nm}$ in a UVVisible spectrophotometer (Model 6305; Jenway, Barloworld Scientific, Dunmow, United Kingdom) [24] (Figure 2).

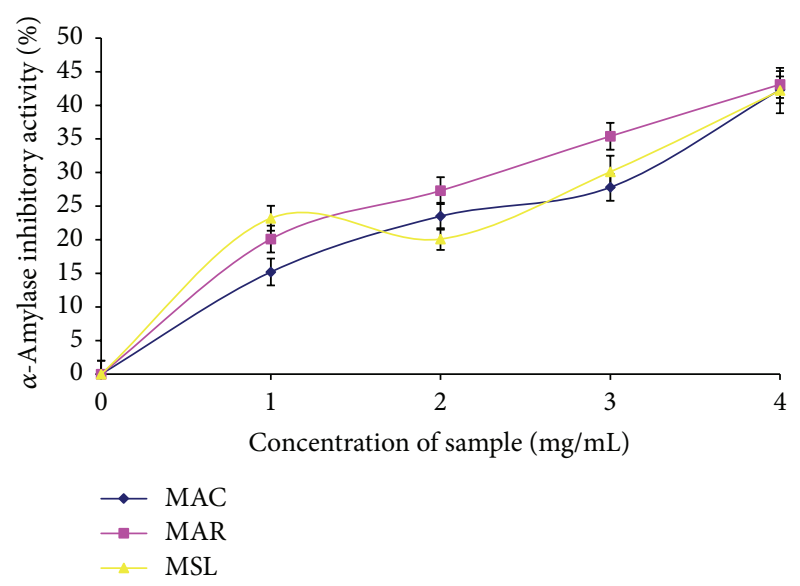

FIGURE 2: $\alpha$-Amylase inhibitory activity of Musa sapientum (Latundan banana) (MSL), Musa acuminata (Cavendish banana) (MAC), and Musa acuminate (Red Dacca) (MAR).

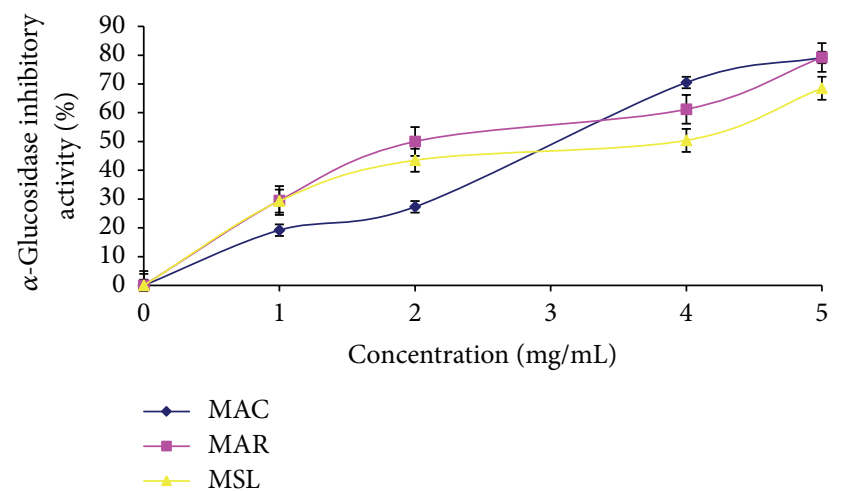

FIgURE 3: $\alpha$-Glucosidase inhibitory activity of Musa sapientum (Latundan banana) (MSL), Musa acuminata (Cavendish banana) (MAC), and Musa acuminate (Red Dacca) (MAR).

2.12. $\alpha$-Glucosidase Inhibition Assay. Aqueous sample (50 $\mu \mathrm{L})$ and $100 \mu \mathrm{L}$ of $\alpha$-glucosidase solution $(1.0 \mathrm{U} / \mathrm{mL})$ were incubated at $25^{\circ} \mathrm{C}$ for $10 \mathrm{~min}$. Thereafter, $50 \mu \mathrm{L}$ of $5 \mathrm{M} \mathrm{p}$ nitrophenyl- $\alpha$-D-glucopyranoside solution in $0.1 \mathrm{~mol} \cdot \mathrm{L}^{-1}$ phosphate buffer ( $\mathrm{pH}$ 6.9) was added. The reaction mixture was then incubated at $25^{\circ} \mathrm{C}$ for $5 \mathrm{~min}$, and then absorbance was measured at $405 \mathrm{~nm}$ in the spectrophotometer. The $\alpha$ glucosidase inhibitory activity was expressed as percentage inhibition [25] (Figure 3).

2.13. Data Analysis. The results of the three replicates were pooled and expressed as mean \pm standard error (SE). Student's $t$-test, one-way analysis of variance (ANOVA), and the least significance difference (LSD) were carried out [26]. Significance was accepted at $P \leq 0.05 . \mathrm{EC}_{50}$ was determined using linear regression analysis.

\section{Findings}

Table 1 shows the carbohydrate content and glycemic index of three banana varieties. MSL $(51.36 \mathrm{mg} / \mathrm{g})$ had higher 
TABLE 1: The starch, sugar, amylose and amylopectin contents, amylose/amylopectin ratio, and glycemic index (\%) of Musa sapientum (Latundan banana) (MSL), Musa acuminata (Cavendish banana) (MAC), and Musa acuminate (Red Dacca) (MAR).

\begin{tabular}{lccc}
\hline Parameter & MAC & MAR & MSL \\
\hline Starch $(\mathrm{g} / 100 \mathrm{~g})$ & $57.31 \pm 2.62^{\mathrm{b}}$ & $58.13 \pm 2.13^{\mathrm{b}}$ & $51.36 \pm 1.8^{\mathrm{a}}$ \\
Sugar $(\mathrm{g} / 100 \mathrm{~g})$ & $17.87 \pm 0.42^{\mathrm{a}}$ & $19.50 \pm 0.52^{\mathrm{b}}$ & $18.52 \pm 0.45^{\mathrm{b}}$ \\
Amylose content (A) (g/100 g) & $9.67 \pm 0.42^{\mathrm{a}}$ & $10.18 \pm 0.45^{\mathrm{a}}$ & $12.84 \pm 0.63^{\mathrm{b}}$ \\
Amylopectin content (Am) (g/100 g) & $47.64 \pm 1.25^{\mathrm{b}}$ & $47.95 \pm 1.67^{\mathrm{b}}$ & $38.52 \pm 1.12^{\mathrm{a}}$ \\
GI (\%) & $45.49 \pm 1.25^{\mathrm{a}}$ & $44.95 \pm 1.33^{\mathrm{a}}$ & $41.33 \pm 0.95^{\mathrm{b}}$ \\
A/Am & 0.20 & 0.23 & 0.33 \\
\hline
\end{tabular}

Value represents mean \pm standard deviation of triplicate readings. Values with the same superscript letter on the same row are not significantly different $(P>$ 0.05).

TABLE 2: Total phenol and flavonoid content and $\mathrm{EC}_{50}$ values of DPPH radical scavenging ability and inhibition of $\alpha$-amylase and $\alpha$ glucosidase activities of Musa sapientum (Latundan banana) (MSL), Musa acuminata (Cavendish banana) (MAC), and Musa acuminate (Red Dacca) (MAR).

\begin{tabular}{|c|c|c|c|c|}
\hline Samples & MAC & MAR & MSL & Acarbose \\
\hline Total phenol (mg GAE/g) & $0.94 \pm 0.01^{\mathrm{a}}$ & $1.07 \pm 0.02^{\mathrm{b}}$ & $0.96 \pm 0.03^{\mathrm{a}}$ & \\
\hline Vitamin C (mg/g) & $1.01 \pm 0.03^{\mathrm{a}}$ & $0.95 \pm 0.03^{\mathrm{a}}$ & $0.96 \pm 0.02^{\mathrm{a}}$ & \\
\hline ABTS (mmol TEAC/g) & $5.03 \pm 0.08^{\mathrm{a}}$ & $4.98 \pm 0.11^{\mathrm{a}}$ & $5.01 \pm 0.04^{\mathrm{a}}$ & \\
\hline $\mathrm{DPPH}(\mathrm{mg} / \mathrm{mL})$ & $21.84 \pm 1.25^{\mathrm{b}}$ & $18.09 \pm 0.98^{\mathrm{a}}$ & $16.33 \pm 1.05^{\mathrm{a}}$ & \\
\hline$\alpha$-Amylase $(\mathrm{mg} / \mathrm{mL})$ & $4.27 \pm 0.13^{\mathrm{c}}$ & $3.95 \pm 0.10^{\mathrm{a}}$ & $4.09 \pm 0.05^{\mathrm{b}}$ & $0.18 \pm 0.02^{\mathrm{d}}$ \\
\hline$\alpha$-Glucosidase (mg/mL) & $3.09 \pm 0.15^{\mathrm{a}}$ & $3.02 \pm 0.12^{\mathrm{a}}$ & $3.47 \pm 0.10^{\mathrm{b}}$ & $0.22 \pm 0.01^{\mathrm{c}}$ \\
\hline
\end{tabular}

Values represent mean \pm standard deviation of triplicate readings. Values with the same superscript letter on the same row are not significantly different $(P>$ 0.05).

starch content than other varieties; however, there was no significant $(P>0.05)$ difference in the starch content of MAC (57.31 mg/g) and MAR (58.13 mg/g). MAC (17.87 mg/g) had lower sugar content than MAR $(19.50 \mathrm{mg} / \mathrm{g})$ and MSL $(18.52 \mathrm{mg} / \mathrm{g})$. The amylose content of MAC $(9.67 \mathrm{mg} / \mathrm{g})$ and MSL $(10.18 \mathrm{mg} / \mathrm{g})$ was not significantly $(P>0.05)$ different but lower than amylose content of MAR $(12.84 \mathrm{mg} / \mathrm{g})$. Moreover, MSL had lower amylopectin content than MAC and MAR. The amylose/amylopectin ratio of the banana samples ranges from 0.20 to 0.33 . The glycemic index of banana varieties as shown in Table 1 indicates that MSL (41.33\%) had lower glycemic index compared to other varieties. There was no significant difference in the glycemic index between MAC (45.49\%) and MAR (44.95\%) varieties.

The total phenol content of MAC, MAR, and MSL was $0.94 \mathrm{mg} \mathrm{GAE} / \mathrm{g}, 1.07 \mathrm{mg} \mathrm{GAE} / \mathrm{g}$, and $0.96 \mathrm{mg} \mathrm{GAE} / \mathrm{g}$, respectively (Table 2 ). The results also revealed that there was no significant difference in the vitamin $\mathrm{C}$ contents and ABTS radical scavenging activity of the three banana varieties (Table 2). Furthermore, the banana varieties scavenged DPPH radical in a dose dependent manner. However, $\operatorname{MAR}\left(\mathrm{IC}_{50}=18.09 \mathrm{mg} / \mathrm{mL}\right)$ and $\mathrm{MSL}\left(\mathrm{IC}_{50}=16.33 \mathrm{mg} / \mathrm{mL}\right)$ varieties had higher radical scavenging activity than MAC $\left(\mathrm{IC}_{50}=21.84 \mathrm{mg} / \mathrm{mL}\right)$. The samples also inhibited $\alpha$-amylase and $\alpha$-glucosidase activities in a dose dependent manner, but $\operatorname{MAR}\left(\mathrm{IC}_{50}=3.95 \mathrm{mg} / \mathrm{mL}\right)$ and $\mathrm{MSL}\left(\mathrm{IC}_{50}=4.09 \mathrm{mg} / \mathrm{mL}\right)$ had the highest $\alpha$-amylase activity compared to $\mathrm{MAC}\left(\mathrm{IC}_{50}=\right.$ $4.27 \mathrm{mg} / \mathrm{mL}$ ). The result on $\alpha$-glucosidase activity of the samples revealed that $\mathrm{MAC}\left(\mathrm{IC}_{50}=3.09 \mathrm{mg} / \mathrm{mL}\right)$ and $\mathrm{MAR}\left(\mathrm{IC}_{50}\right.$ $=3.02 \mathrm{mg} / \mathrm{mL}$ ) had the highest $\alpha$-glucosidase activity with no significant difference. However, MSL $\left(\mathrm{IC}_{50}=3.47 \mathrm{mg} / \mathrm{mL}\right)$ had the least $\alpha$-glucosidase activity amongst the samples. Furthermore, the Pearson correlation coefficient (Table 3) revealed that there was significant correlation $(P=0.01)$ between the phytoconstituents (total phenol, total flavonoid, and vitamin $\mathrm{C}$ contents) and the enzyme inhibition as well as antioxidant properties (DPPH and ABTS radical scavenging abilities) of the cultivars.

\section{Discussion}

Previous studies have shown that control of blood sugar and variations in glycemic index of different foods may be helpful in the management of type 2 diabetes $[4,27]$. Consumption of starch-rich foods can increase postprandial blood glucose and insulin response [28]. In this study, the starch content of the banana varieties was moderately higher than that of some tropical fruits but lower than that of breadfruit reported by Oboh et al. [29]. However MSL banana had the lowest starch content compared to MAC and MAR. Consumption of lower starchy foods may contribute to decrease in glucose response; therefore, it could be an important factor in the management of diabetes. Hoover-Plow et al. [30] reported that low levels of starch content in apple and banana contributed to low blood glucose response in some selected diabetic patients. Furthermore, the observed low sugar content of the banana varieties could be beneficial especially to diabetic patients due to the fact that high consumption of sugars can increase the risk of type 2 diabetes and its complications such as cardiovascular diseases [31].

Amylose/amylopectin ratio is one of the major factors that influence blood glucose response and/or GI of food 
TABLE 3: Pearson correlation coefficients for total phenol, vitamin C contents, amylase and glucosidase inhibitory, and free radical (DPPH and ABTS) scavenging abilities of the banana cultivars.

\begin{tabular}{lcccc}
\hline & $\alpha$-Amylase & $\alpha$-Glucosidase & $\begin{array}{c}\text { DPPH radical } \\
\text { Scavenging ability }\end{array}$ & $\begin{array}{c}\text { ABTS radical } \\
\text { Scavenging ability }\end{array}$ \\
\hline TP & 0.283 & 0.590 & 0.207 & 0.032 \\
VC & 0.829 & 0.952 & 0.916 & 0.976 \\
\hline
\end{tabular}

All correlation coefficients are significant at $P<0.01$ (two-tailed).

$\mathrm{TP}=$ total phenol; $\mathrm{VC}=$ vitamin $\mathrm{C}$.

[32]. This is due to the fact that diets rich in amylose with low amylopectin content can induce low glycemic blood and insulin response [33]. Our findings revealed that the studied banana cultivars had low amylose and high amylopectin contents. The implication of this result is that starches with open branch structure that consist of large proportions of amylopectin than amylose are susceptible to enzymatic attack which can lead to rapid release of glucose into the bloodstream and hyperglycemia [28, 34]. However, despite the high amylopectin content, the banana cultivars displayed low glycemic response as revealed by their GI values.

Glycemic index is usually classified into low GI (0-55), medium GI (56-69), and high GI ( $\geq 70)$ using glucose as reference [29]. Our results revealed that MSL had lower GI than MAC and MAR. The low GI value exhibited by MSL cultivar could be attributed to its lower amylose and amylopectin contents compared to other studied cultivars. The high amylose in the MSL cultivar could slow down the digestion rate as a result of highly branched amylose structure, thereby limiting the rate at which glucose is released into the blood. This is contrary to the low amylose content which was observed in MAR and MAC samples. Therefore, consumption of MSL appears to be the best in the management of diabetes as it will reduce hyperglycemia and reduce the risk of diabetic complications especially cardiovascular diseases.

Chronic hyperglycemia has been implicated in the early onset and pathogenesis of diabetes and its complication [35]. There are indications that chronic hyperglycemia can induce the production of reactive oxygen species and ultimately lead to oxidative stress and pancreatic cell damage $[3,35]$. The three banana cultivars exhibited radical scavenging activities as typified by their ABTS and DPPH radical scavenging abilities (Table 1). The result, therefore, agrees with the findings of Shian et al. [14] who reported that banana fruits have antioxidant properties. The radical scavenging activity of the banana samples has strong correlation with the vitamin C content but low correlation with phenolic contents (Table 3 ). Moreover previous finding has revealed that vitamin $\mathrm{C}$ is a strong antioxidant molecule and scavenger of oxygen-derived radicals such as hydroxyl $(\mathrm{OH})$ radical and singlet oxygen [36], although the antioxidant properties of many plants alongside with their radical scavenging ability have been linked to their phenolic content $[37,38]$.

Rapid degradation of starchy foods by carbohydratehydrolyzing enzymes ( $\alpha$-amylase and $\alpha$-glucosidase) leads to hyperglycemia [3]. Most common therapeutic approach to the treatment and management of diabetes involves the use of synthetic inhibitors of $\alpha$-amylase and $\alpha$-glucosidase activities to retard the release of glucose into the blood stream [39]. However, the use of these synthetic inhibitors such as acarbose and voglibose causes some side effects such as abdominal cramps, flatulence, and meteorism [40]. Dietary approach to the management of diabetes using plant with natural inhibitors of $\alpha$-amylase and $\alpha$-glucosidase has a greater advantage. Our findings revealed that the three banana cultivars inhibited $\alpha$-amylase and $\alpha$-glucosidase activities in a dose dependent manner. MAR cultivar had a higher inhibitory effect on $\alpha$-glucosidase than $\alpha$-amylase. Our findings revealed that there is a correlation between total phenol content and $\alpha$-amylase and $\alpha$-glucosidase inhibitory activities of the banana cultivars. A strong correlation was observed between total phenol content and $\alpha$-glucosidase inhibition compared to amylase inhibition. This result correlates with the findings of [41] which reported a higher glucosidase activity of phenolic samples from soybean than its corresponding amylase activity. Moreover higher inhibition of $\alpha$-glucosidase activity than its corresponding $\alpha$-amylase is of great pharmaceutical importance in ameliorating the side effects induced by excess inhibition of $\alpha$-amylase [9].

\section{Conclusion}

The knowledge of dietary fruits and vegetables to control and reduce hyperglycemia is essential in the treatment of diabetes. This is because dietary management is crucial to controlling spikes in blood glucose levels. In this study, the banana (MSL, MAR, and MAC) cultivars exhibited low GI index and antioxidant activities as typified by their radical scavenging abilities. The samples also had inhibitory effect on $\alpha$-amylase and $\alpha$-glucosidase activities. These abilities could be attributed to their phytochemicals which therefore justify their recommendations for the management of diabetes.

\section{Competing Interests}

The authors declare no conflict of interests.

\section{References}

[1] M. J. Fowler, "Microvascular and macrovascular complications of diabetes," Clinical Diabetes, vol. 26, no. 2, pp. 77-82, 2008.

[2] C. U. Rajeshwari, R. I. Shobha, and B. Andallu, "Oxidative stress and antioxidant effects of herbs and spices in diabetes," Annals of Phytomedicine, vol. 2, no. 2, pp. 13-27, 2013. 
[3] G. Oboh, I. A. Akinbola, A. O. Ademosun et al., "Essential oil from clove bud (Eugenia aromatica Kuntze) Inhibit key enzymes relevant to the management of type-2 diabetes and some pro-oxidant induced lipid peroxidation in rats pancreas in vitro," Journal of Oleo Science, vol. 64, no. 7, pp. 775-782, 2015.

[4] W. Willett, J. Manson, and S. Liu, "Glycemic index, glycemic load, and risk of type 2 diabetes," The American Journal of Clinical Nutrition, vol. 76, no. 1, pp. 274-280, 2002.

[5] F. M. Sacks, V. J. Carey, C. A. M. Anderson et al., "Effects of high vs low glycemic index of dietary carbohydrate on cardiovascular disease risk factors and insulin sensitivity: the OmniCarb randomized clinical trial," JAMA-Journal of the American Medical Association, vol. 312, no. 23, pp. 2531-2541, 2014.

[6] C. K. Roberts and S. Liu, "Effects of glycemic load on metabolic health and type 2 diabetes mellitus," Journal of Diabetes Science and Technology, vol. 3, no. 4, pp. 697-704, 2009.

[7] P. Saleh, B. Asghari, M. A. Esmaeil, H. Dehghan, and I. Ghazi, " $\alpha$-Glucosidase and $\alpha$-amylase inhibitory effect and antioxidant activity of ten plant extracts traditionally used in Iran for diabetes," Journal of Medicinal Plants Research, vol. 7, no. 6, pp. 257-266, 2013.

[8] E. A. Mohamed, M. Ahmad, L. F. Ang, M. Z. Asmawi, and M. F. Yam, "Evaluation of $\alpha$-glucosidase inhibitory effect of $50 \%$ ethanolic standardized extract of orthosiphonstamineusbenth in normal and streptozotocin-induced diabetic rats," $B M C$ Complement Alternative Medicine, vol. 12, p. 176, 2012.

[9] H. Bischoff, "Pharmacology of $\alpha$-glucosidase inhibition," European Journal of Clinical Investigation, vol. 24, supplement 3, pp. 3-10, 1994.

[10] K. Rahman, "Studies on free radicals, antioxidants, and cofactors," Clinical Interventions in Aging, vol. 2, no. 2, pp. 219-236, 2007.

[11] R. C. Ruhe and R. B. McDonald, "Use of antioxidant nutrients in the prevention and treatment of Type 2 diabetes," Journal of the American College of Nutrition, vol. 20, no. 5, 2001.

[12] A. F. M. Alkarkhi, S. Ramli, S. Y. Yeoh, and A. M. Easa, "Physiochemical properties of banana peel flour as influenced by variety and stage of ripeness: multivariate statistical analysis," Asian Journal of Food Agro-Industry, vol. 3, pp. 349-362, 2010.

[13] K. Kanazawa and H. Sakakibara, "High content of dopamine, a strong antioxidant, in cavendish banana," Journal of Agricultural and Food Chemistry, vol. 48, no. 3, pp. 844-848, 2000.

[14] T. E Shian, A. Abdullah, K. H. Musa, M. Y. Maskat, and MA. Ghani, "Antioxidant properties of three banana cultivars (Musa acuminate 'Berangan", 'Mas' and 'Raja') extracts,' Sains Malaysiana, vol. 41, no. 3, pp. 319-324, 2012.

[15] V. Lakshmi, S. K. Agarwal, J. A. Ansari, A. A. Mahdi, and A. K. Srivastava, "Antidiabetic potential of Musa paradisiaca in Streptozotocin-induced diabetic rats," The Journal of Phytopharmacology, vol. 3, no. 2, pp. 77-81, 2014.

[16] B. C. Adedayo, S. I. Oyeleye, I. I. Ejakpovi, and G. Oboh, "Effects of hot water treatment on the radicals scavenging, lipid peroxidation, and $\alpha$-amylase and $\alpha$-glucosidase inhibitory abilities of Crassocephalum crepidioides leaves," Nutrafoods, vol. 14, no. 4, pp. 217-225, 2015.

[17] M. O. Onitilo, L. O. Sanni, I. Daniel, B. Maziya-Dixon, and A. Dixon, "Physicochemical and functional properties of native starches from cassava varieties in Southwest Nigeria," Journal of Food, Agriculture and Environment, vol. 5, no. 3-4, pp. 108-114, 2007.
[18] B. O. Juliano, "A simplified assay for milled-rice amylose," Cereal Science Today, vol. 16, pp. 334-338, 1971.

[19] F. Brouns, I. Bjorck, K. N. Frayn et al., "Glycaemic index methodology," Nutrition Research Reviews, vol. 18, no. 1, pp. 145171, 2005.

[20] V. L. Singleton, R. Orthofer, and R. M. Lamuela-Raventos, "Analysis of total phenols and other oxidation substrates and antioxidants by means of Folin-Ciocaltau reagent," Methods in Enzymology, vol. 299, pp. 152-178, 1999.

[21] A. O. Ademiluyi, G. Oboh, F. P. Aragbaiye, S. I. Oyeleye, and O. B. Ogunsuyi, "Antioxidant properties and in vitro $\alpha$ amylase and $\alpha$-glucosidase inhibitory properties of phenolics constituents from different varieties of Corchorus spp.", Journal of Taibah University Medical Sciences, vol. 10, no. 3, pp. 278-287, 2015.

[22] R. Re, N. Pellegrini, A. Proteggente, A. Pannala, M. Yang, and C. Rice-Evans, "Antioxidant activity applying an improved ABTS radical cation decolorization assay," Free Radical Biology and Medicine, vol. 26, no. 9-10, pp. 1231-1237, 1999.

[23] M. A. Gyamfi, M. Yonamine, and Y. Aniya, "Free-radical scavenging action of medicinal herbs from Ghana: Thonningia sanguinea on experimentally-induced liver injuries," General Pharmacology: The Vascular System, vol. 32, no. 6, pp. 661-667, 1999.

[24] Worthington Biochemical Corp, Worthington Enzyme and Related Biochemicals, Worthington Biochemical Corp, Freehold, NJ, USA, 2000.

[25] E. Apostolidis, Y.-I. Kwon, and K. Shetty, "Inhibitory potential of herb, fruit, and fungal-enriched cheese against key enzymes linked to type 2 diabetes and hypertension," Innovative Food Science and Emerging Technologies, vol. 8, no. 1, pp. 46-54, 2007.

[26] J. H. Zar, Biostatistical Analysis, Prentice-Hall, Upper Saddle River, NJ, USA, 1984.

[27] G. Riccardi, A. A. Rivellese, and R. Giacco, "Role of glycemic index and glycemic load in the healthy state, in prediabetes, and in diabetes," American Journal of Clinical Nutrition, vol. 87, no. 1, pp. 269S-274S, 2008.

[28] H. Patel, R. Day, P. J. Butterworth, and P. R. Ellis, "A mechanistic approach to studies of the possible digestion of retrograded starch by $\alpha$-amylase revealed using a log of slope (LOS) plot," Carbohydrate Polymers, vol. 113, pp. 182-188, 2014.

[29] G. Oboh, A. O. Ademosun, M. Akinleye, O. S. Omojokun, A. A. Boligon, and M. L. Athayde, "Starch composition, glycemic indices, phenolic constituents, and antioxidative and antidiabetic properties of some common tropical fruits," Journal of Ethnic Foods, vol. 2, no. 2, pp. 64-73, 2015.

[30] J. Hoover-Plow, J. Savesky, and G. Dailey, "The glycemic response to meals with six different fruits in insulin-dependent diabetics using a home blood-glucose monitoring system," American Journal of Clinical Nutrition, vol. 45, no. 1, pp. 92-97, 1987.

[31] B. V. Howard and J. Wylie-Rosett, "Sugar and cardiovascular disease: a statement for healthcare professionals from the Committee on Nutrition of the Council on Nutrition, Physical Activity, and Metabolism of the American Heart Association," Circulation, vol. 106, no. 4, pp. 523-527, 2002.

[32] S. N. Shanita, H. Hasnah, and C. W. Khoo, "Amylose and amylopectin in selected Malaysian foods and its relationship to glycemic index," Sains Malaysiana, vol. 40, no. 8, pp. 865-870, 2011.

[33] M. Kabir, S. W. Rizkalla, M. Champ et al., "Dietary amyloseamylopectin starch content affects glucose and lipid metabolism 
in adipocytes of normal and diabetic rats," Journal of Nutrition, vol. 128, no. 1, pp. 35-42, 1998.

[34] C. E. Wiseman, J. A. Higgins, G. S. Denyer, and J. C. Brand Miller, "Amylopectin starch induces nonreversible insulin resistance in rats," Journal of Nutrition, vol. 126, no. 2, pp. 410-415, 1996.

[35] M. Valko, D. Leibfritz, J. Moncol, M. T. D. Cronin, M. Mazur, and J. Telser, "Free radicals and antioxidants in normal physiological functions and human disease," International Journal of Biochemistry and Cell Biology, vol. 39, no. 1, pp. 44-84, 2007.

[36] O. Arrigoni and M. C. De Tullio, "Ascorbic acid: much more than just an antioxidant," Biochimica et Biophysica Acta (BBA)General Subjects, vol. 1569, no. 1-3, pp. 1-9, 2002.

[37] O. Ademosun, G. Oboh, T. M. Adewuni, A. J. Akinyemi, and T. A. Olasehinde, "Antioxidative properties and inhibition of key enzymes linked to type-2 diabetes by snake tomato (Tricosanthes cucumerina) and two tomato (Lycopersicon esculentum) varieties," African Journal of Pharmacy and Pharmacology, vol. 7, no. 33, pp. 2358-2365, 2013.

[38] G. Oboh, A. O. Ademiluyi, A. O. Ademosun et al., "Phenolic extract from Moringa oleifera leaves inhibits key enzymes linked to erectile dysfunction and oxidative stress in rats' penile tissues," Biochemistry Research International, vol. 2015, Article ID 175950, 8 pages, 2015.

[39] N. Saito, H. Sakai, H. Sekihara, and Y. Yajima, "Effect of an a-glucosidase inhibitor (Voglibose), in combination with sulphonyl urea, on glycemic control in type 2 diabetes patients," Journal of International Medical Research, vol. 26, pp. 219-232, 1998.

[40] G. Oboh, I. A. Akinbola, A. O. Ademosun et al., "Essential oil from clove bud (Eugenia aromatica Kuntze) inhibit key enzymes relevant to the management of type- 2 diabetes and some prooxidant induced lipid peroxidation in rats pancreas in vitro," Journal of Oleo Science, vol. 64, no. 7, pp. 775-782, 2015.

[41] A. O. Ademiluyi and G. Oboh, "Soybean phenolic-rich extracts inhibit key-enzymes linked to type 2 diabetes ( $\alpha$-amylase and $\alpha$-glucosidase) and hypertension (angiotensin I converting enzyme) in vitro," Experimental and Toxicologic Pathology, vol. 65, no. 3, pp. 305-309, 2013. 

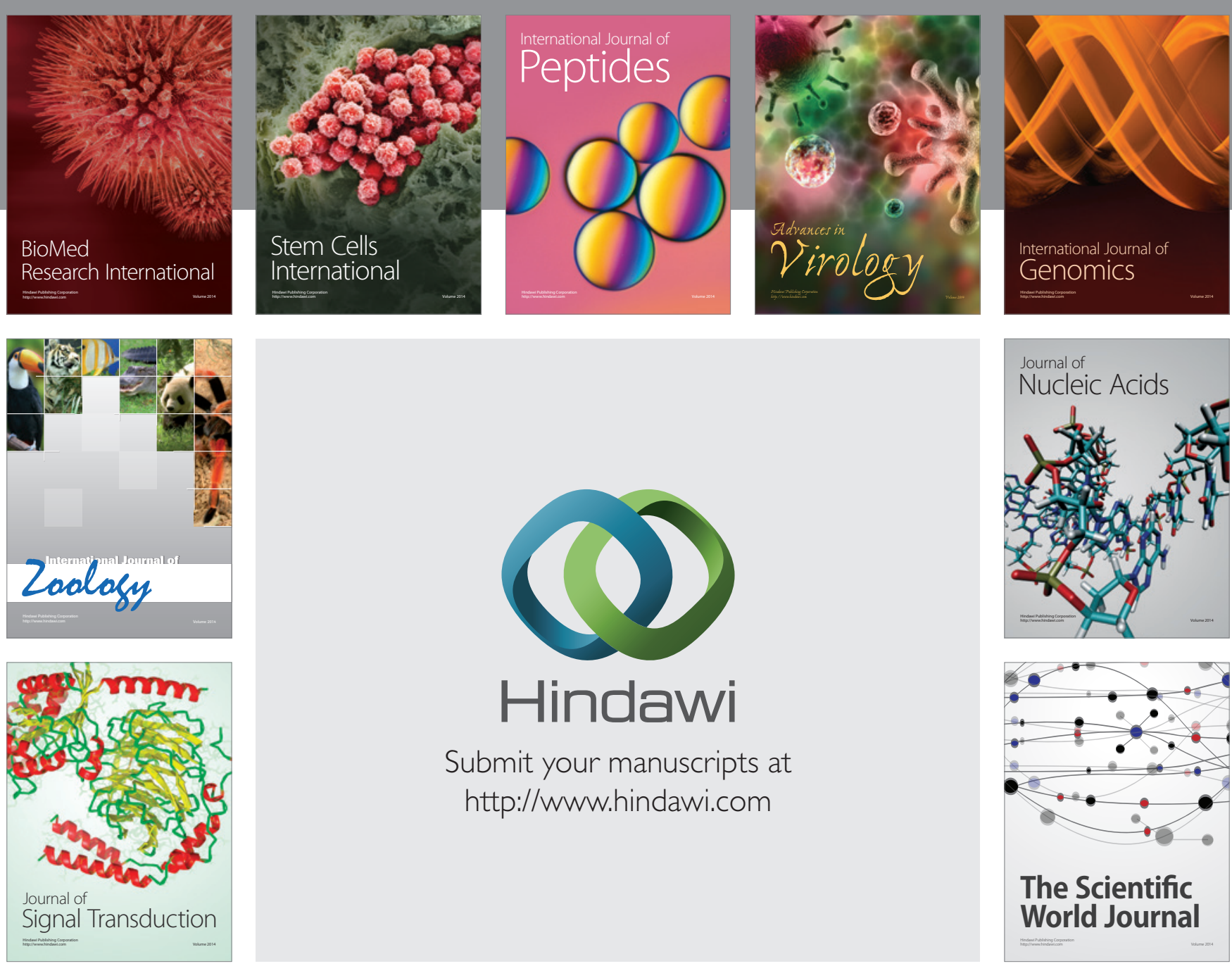

Submit your manuscripts at

http://www.hindawi.com
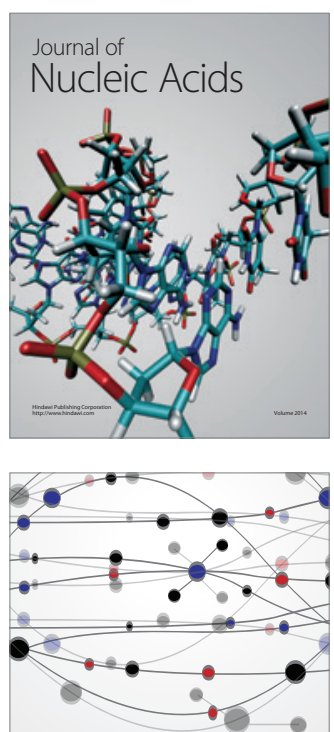

The Scientific World Journal
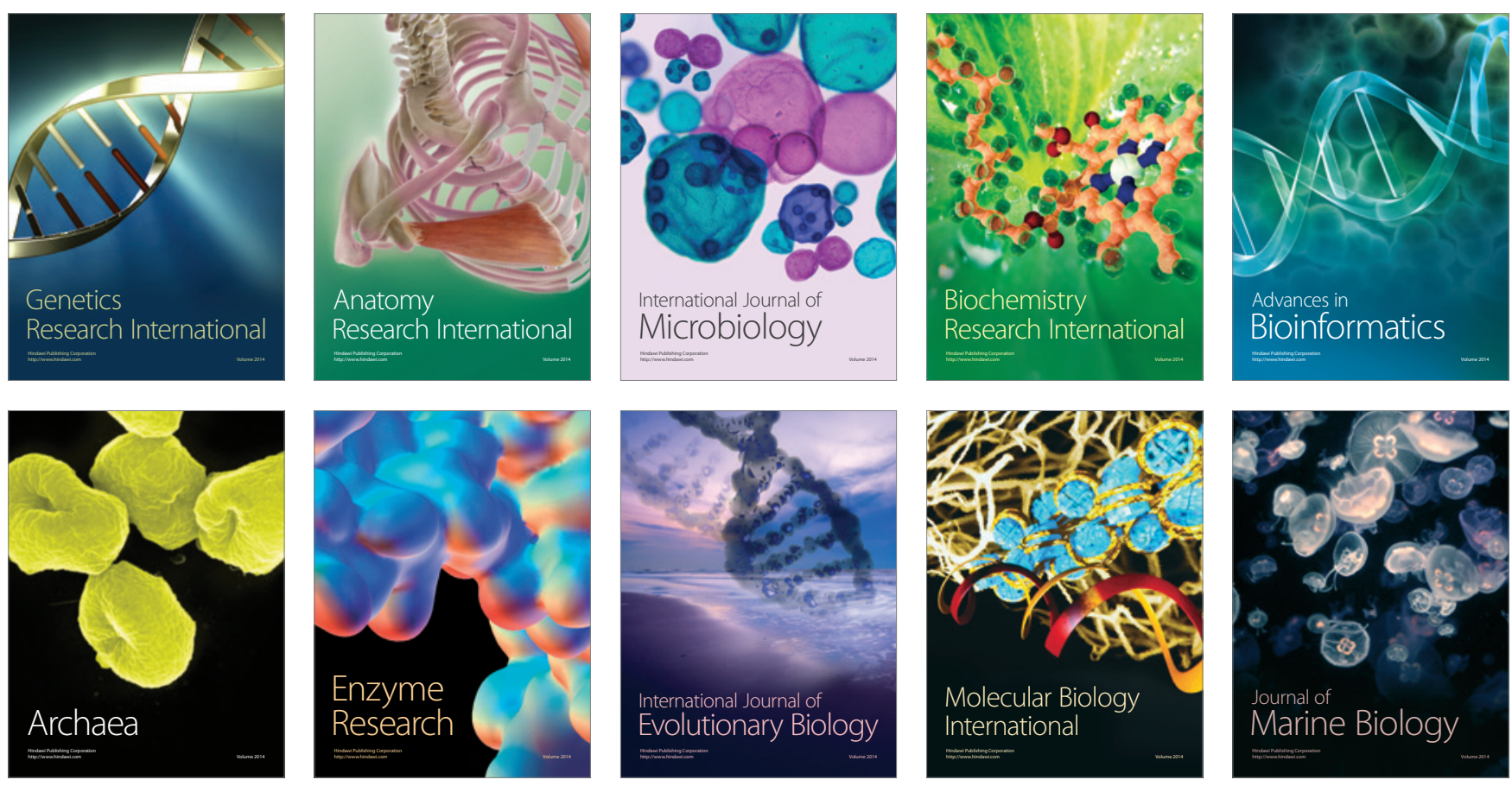